\title{
Electrocatalytic Production of Hydrogen Using Iron Sulfur Cluster
}

\author{
Khalaf M Alenezi ${ }^{1}$, Hamed Alshammari ${ }^{1}$ \\ ${ }^{1}$ Department of Chemistry, Faculty of Science, University of Hail, Hail, Kingdom of Saudi Arabia \\ Correspondence: Khalaf M Alenezi, Department of Chemistry, Faculty of Science, University of Hail, Hail, Kingdom \\ of Saudi Arabia. E-mail: k.alenezi@uoh.edu.sa.
}

Received: February 28, 2017 Accepted: March 20, 2017 Online Published: March 27, 2017

doi:10.5539/ijc.v9n2p52

URL: https://doi.org/10.5539/ijc.v9n2p52

\begin{abstract}
In response to the energy crisis, rising fossil fuel costs and global climate warming, this study focuses on the electrocatalytic reduction of proton into hydrogen using an iron sulfur cluster in the presence of pentafluorothiophenol. The direct reduction of pentafluorothiophenol at vitreous carbon electrode occurs at $\mathrm{E}_{\mathrm{p}}-1.3 \mathrm{~V} v \mathrm{Ag} / \mathrm{AgCl}$ in Tetrabutylammonium tetrafluoroborate $\left[\mathrm{Bu}_{4} \mathrm{~N}\right]\left[\mathrm{BF}_{4}\right]-\mathrm{DMF}$ solution. Interestingly, in the presence of Iron Sulfur Cluster $\left[\mathrm{Fe}_{4} \mathrm{~S}_{4}(\mathrm{SPh})_{4}\right]\left[\mathrm{Bu}_{4} \mathrm{~N}\right]_{2}$, the reduction potential shifts significantly to $-0.98 \mathrm{~V} v \mathrm{sg} / \mathrm{AgCl}$. Based on gas chromatography analysis, the formation of $\mathrm{H}_{2}$ has been confirmed with a current efficiency of $c a$. $63 \%$ after two hours, while the chemical yield at the carbon electrode was about $46 \%$. On the other hand, no $\mathrm{H}_{2}$ gas was detected without catalyst. Importantly, the increment of the concentration of acid (up to 18 equivalents) led to a positive shifting in the reduction potential until a value of $0.18 \mathrm{~V}$. These results reflect the exquisite electrocatalytic efficiency of the protein-like iron sulfur cluster in Hydrogen Evolution Reaction (HER).
\end{abstract}

Keywords: electrocatalysis, hydrogen, iron sulfur cluster

\section{Introduction}

The exquisite target of using hydrogen as sustainable energy has attracted significant attention because of many advantages including its innocent impact on the environment with energy conversion free of $\mathrm{CO}_{2}$ emission. However, the ultimate problem resulting from its production - mostly from fossil fuels such as coal and oil-remains in the release of $\mathrm{CO}_{2}$ which endanger the environment and global health (Aulice, 2004 \& Maria, 2007) Therefore, researchers are interested in developing many other methods for hydrogen production including water splitting and proton reduction (Artero, 2014; Bhugun, 1996; Kumar, 2010; Bak, 2002 \& Kelly, 2008).

Transition metal complexes are of great interest for electrocatalytic reduction of proton into hydrogen at low potential (Perutz, 2012; Kellett, 1985; Koper, 2013; David, 2015 \& Han, 2014). Alenezi (2017) has studied the electrochemical catalysis of proton reduction into hydrogen using mesotetrakis-(pentafluorophenyl)porphyrin iron(III) chloride in the presence o triethylamine hydrochloride $\mathrm{f}_{\mathrm{E}} \mathrm{NHCl}$ as source of proton. The reduction potential $\mathrm{E}_{\mathrm{p}}$ was marked with a significant shift from $-1.6 \mathrm{~V}$ to $-1.3 \mathrm{~V} v \mathrm{Ag} / \mathrm{AgCl}$ in the presence of the catalyst. A current efficiency of $\mathrm{ca}$. $58 \%$ after $3.8 \mathrm{~h}$ was recorded, with a yield of $8 \mu$ moles and a turnover number of 8 while the chemical yield was about $80 \%$ On the other hand, $\left\{\mathrm{Fe}_{4} \mathrm{~S}_{4}\right\}$-clusters have been known for over 40 years. However, the studies of their electrocatalytic properties have been extremely limited. These entities, commonly known as iron sulfur clusters, play important roles in biological systems; they are involved in electron transfer as well as catalytic, structural, and sensory roles (Pickett, 2003 $\&$ Goh, 1996). In this study, we focus on the electrochemical catalysis of proton reduction into hydrogen using the synthetic iron sulfur complex $\left[\mathrm{Fe}_{4} \mathrm{~S}_{4}(\mathrm{SPh})_{4}\right]^{2-}$ at the vitreous carbon electrode in $\left[\mathrm{Bu}_{4} \mathrm{~N}\right]\left[\mathrm{BF}_{4}\right]-\mathrm{DMF}$ solution.

\section{Methed}

Pentafluorothiophenol was purchased from Aldrich and used as received. N,N/-dimethylformamide (DMF) was purified by distillation over calcium hydride. The iron sulfur cluster $\left[\mathrm{Fe}_{4} \mathrm{~S}_{4}(\mathrm{SPh})_{4}\right]\left[\mathrm{Bu}_{4} \mathrm{~N}\right]_{2}$ was prepared according to the literature method (Pamphilis, 1974). Electrochemical experiments were conducted to evaluate the electrocatalytic production of hydrogen by iron sulfur clusters following a reported procedure (Alenezi, 2017).

Cyclic voltammetry experiments were carried out using an Autolab PGSTAT 30 potentiostat. A conventional three-electrode arrangement was employed, consisting of a vitreous carbon working electrode $\left(0.07 \mathrm{~cm}^{2}\right)$, a platinum wire as the auxiliary electrode $\left(2 \mathrm{~cm}^{2}\right)$, and $\mathrm{Ag}^{+} / \mathrm{AgCl}$ as a reference electrode.

The electrolysis cell, containing $14 \mathrm{ml}$ of a solution of electrolyte $\left[\mathrm{NBu}_{4}\right]\left[\mathrm{BF}_{4}\right], 0.2 \mathrm{M}$ in DMF, was degassed with argon 
gas. $5 \mathrm{ml}$ of this solution was placed in the working electrode compartment. About 9-10 $\mathrm{ml}$ of the gas phase took place at the working electrode part. $1 \mathrm{mM}$ of the catalyst $\left[\mathrm{Fe}_{4} \mathrm{~S}_{4}(\mathrm{SPh})_{4}\right]^{2-}$ was added and stirred under argon in the electrochemical cell.

The electrolysis was carried out at $-0.85 \mathrm{~V} v s \mathrm{Ag}^{+} / \mathrm{AgCl}$ and the current were recorded during the course of electrolysis vs time; the electrolysis was stopped when the current decayed after two hours. Gas chromatography was carried out using a Perkin-Elmer Clarius 500 instrument, fitted with a $5 \AA$ molecular sieve column (800/100 mesh, 6' x 1/8") and thermal conductivity detector. The operating conditions were: $80^{\circ} \mathrm{C}$ oven temperature, $0.5 \mathrm{ml}$ injected volume, and 10 min retention time. The external standard calibration was performed on the same day

\section{Results}

\subsection{Cyclic Voltammetry of $1 \mathrm{mM}\left[\mathrm{Fe}_{4} \mathrm{~S}_{4}(\mathrm{SPh})_{4}\right]^{2-}$ in $\mathrm{DMF}-0.2 \mathrm{M}\left[\mathrm{Bu} \mathrm{u}_{4} \mathrm{~N}\right]\left[\mathrm{BF}_{4}\right]$}

The cyclic voltammetry of $\left[\mathrm{Fe}_{4} \mathrm{~S}_{4}(\mathrm{SPh})_{4}\right] 2$ - in non-aqueous electrolytes $\left[\mathrm{Bu}_{4} \mathrm{~N}\right]\left[\mathrm{BF}_{4}\right]-\mathrm{DMF}$ was studied. In this solvent, there is a diffusion-controlled primary reduction step, corresponding to the $\left[\mathrm{Fe}_{4} \mathrm{~S}_{4}(\mathrm{SPh})_{4}\right]^{2-13-}$ couple at $-0.98 \mathrm{~V}$ vs $\mathrm{Ag} / \mathrm{AgCl}$. In addition, a second partly reversible reduction wave was observed at a more negative potential $-1.72 \mathrm{~V}$ vs $\mathrm{Ag} / \mathrm{AgCl}$ (figuer 1). Herein, the electrochemical study was carried out at the first wave reduction of $\left[\mathrm{Fe}_{4} \mathrm{~S}_{4}(\mathrm{SPh})_{4}\right]^{2-}$.

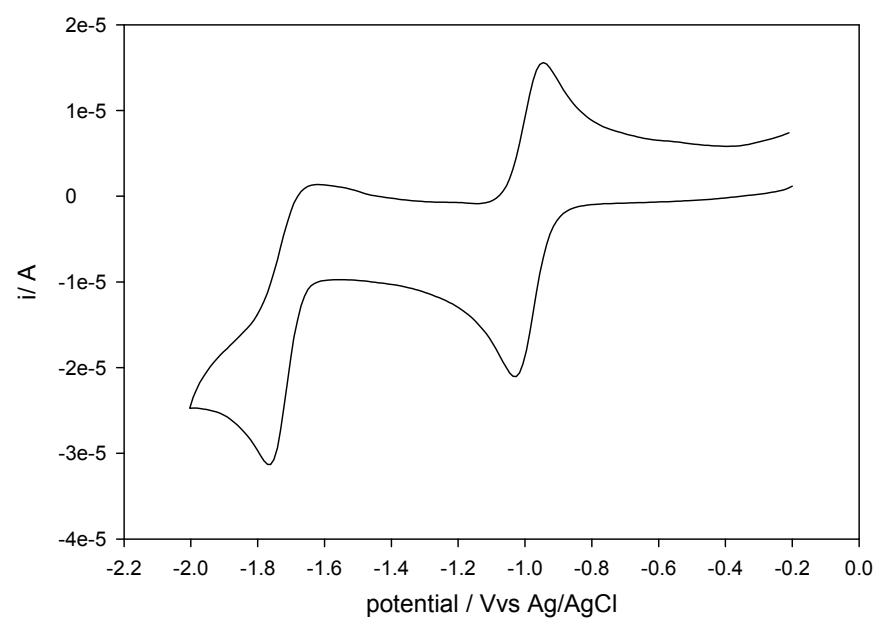

Figure 1. Cyclic voltammetry of $1 \mathrm{mM}\left[\mathrm{Fe}_{4} \mathrm{~S}_{4}(\mathrm{SPh})_{4}\right]^{2-}$ in $\mathrm{DMF}-0.2 \mathrm{M}\left[\mathrm{Bu}_{4} \mathrm{~N}\right]\left[\mathrm{BF}_{4}\right]$; scan rate $100 \mathrm{mVs}^{-1}$, vitreous carbon electrode under $\mathrm{Ar}$ at $25^{\circ} \mathrm{C}$

Figure 2 shows a set of voltammograms recorded at various scan rates for $\left[\mathrm{Fe}_{4} \mathrm{~S}_{4}(\mathrm{SPh})_{4}\right]^{2-} 1 \mathrm{mM}$ in $\mathrm{DMF}-\left[\mathrm{Bu}_{4} \mathrm{~N}\right]\left[\mathrm{BF}_{4}\right]$. The primary reduction process is a diffusion-controlled reversible one-electron step. Thus: (i) the plot of the peak current ${ }^{\mathrm{I}} i_{\mathrm{p}}$ red $\mathrm{Vs} \mathrm{v}^{1 / 2}$ is linear, with an intercept close to zero (Figure 3); (ii) the peak potential separation of the first wave, $\Delta \mathrm{E}_{\mathrm{p}}=\mathrm{E}_{\mathrm{p}}{ }^{\text {ox }}-\mathrm{E}_{\mathrm{p}}{ }^{\text {red }}=\frac{59}{\mathrm{n}} \mathrm{m} V \cdot \Delta \mathrm{E}=70 \mathrm{mV}$ (theoretical separation for a one-electron process is $c a 59 \mathrm{mV}$ at $298 \mathrm{~K}$ ). The diffusion coefficient for $0.5 \mathrm{mM}\left[\mathrm{Fe}_{4} \mathrm{~S}_{4}(\mathrm{SPh})_{4}\right]^{2-}$ is estimated to be $1.42 \times 10^{-5} \mathrm{~cm}^{2} \mathrm{~s}^{-1}$, according to Randles - Sevcik Equation:

$$
\mathrm{I}_{\mathrm{p}}=-\left(2.69 \times 10^{5}\right) n^{3 / 2} \mathrm{C}_{0} \mathrm{D}^{1 / 2} v^{1 / 2} .(\text { Mabbott, 1983) }
$$

The $\mathrm{C}_{0}$ is the bulk concentration in $\mathrm{mol} / \mathrm{cm}^{3}, \mathrm{D}$ is the diffusion coefficient in $\mathrm{cm}^{2} \mathrm{~s}^{-1}, v$ is the potential scan rate in $\mathrm{V} \mathrm{s}^{-1}$, and $\mathrm{I}$ is the current density. The electrocatalysis was carried out at the potential of the first reduction wave of $\left[\mathrm{Fe}_{4} \mathrm{~S}_{4}(\mathrm{SPh})_{4}\right]^{2-}$, in both presence and absence of pentafluorothiophenol. 


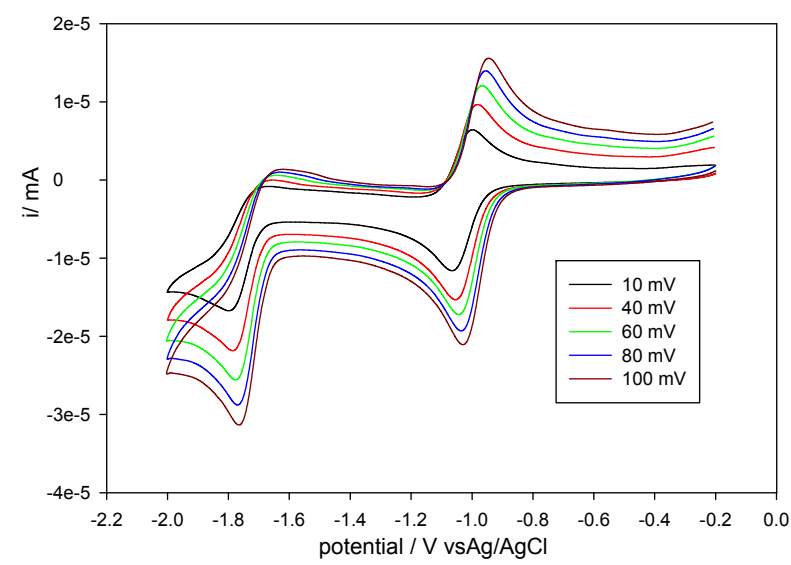

Figure 2. Cyclic voltammograms of $1 \mathrm{mM}\left[\mathrm{Fe}_{4} \mathrm{~S}_{4}(\mathrm{SPh})_{4}\right]^{2}$ at carbon electrode, at different scan-rates in DMF containing $0.1 \mathrm{M}\left[\mathrm{NBu}_{4}\right]\left[\mathrm{BF}_{4}\right]$

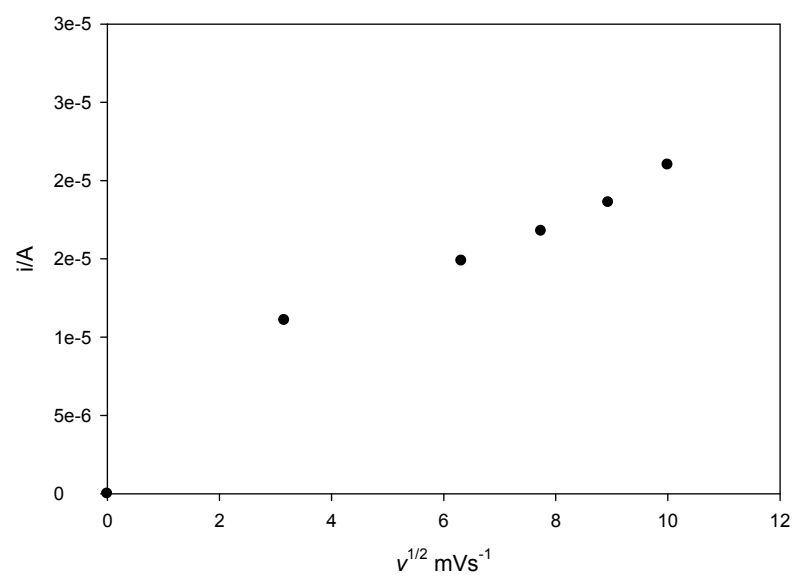

Figure 3. Plot of $\mathrm{i}_{\mathrm{p}}$ red for the $\left[\mathrm{Fe}_{4} \mathrm{~S}_{4}(\mathrm{SPh})_{4}\right]^{2-/ 3}$ couple versus the square-root of the scan-rate

\subsection{Cyclic Voltammetry of $\left[\mathrm{Fe}_{4} \mathrm{~S}_{4}(\mathrm{SPh})_{4}\right]^{2-}$ in the Presence of Pentafluorothiophenol}

We examined the cyclic voltammetry of $\left[\mathrm{Fe}_{4} \mathrm{~S}_{4}(\mathrm{SPh})_{4}\right]^{2-}$ in the presence of pentafluorothiophenol as a source of proton (Figure 4). The primary reduction wave for $\left[\mathrm{Fe}_{4} \mathrm{~S}_{4}(\mathrm{SPh})_{4}\right]^{2-}$ increase in height and became irreversible while increasing the concentration of pentafluorothiophenol, which is consistent with the electrocatalysis of proton reduction by the $\left[\mathrm{Fe}_{4} \mathrm{~S}_{4}(\mathrm{SPh})_{4}\right]^{2-}$ complex. In addition the potential shift is proportional to the concentration of pentafluorothiophenol; at a concentration as high as $18 \mathrm{mM}$, the potential shifts in about $180 \mathrm{mV}$. At high concentrations of pentafluorothiophenyl, we observe a plateau (Figure 5) for the peak current and a precipitate is formed.

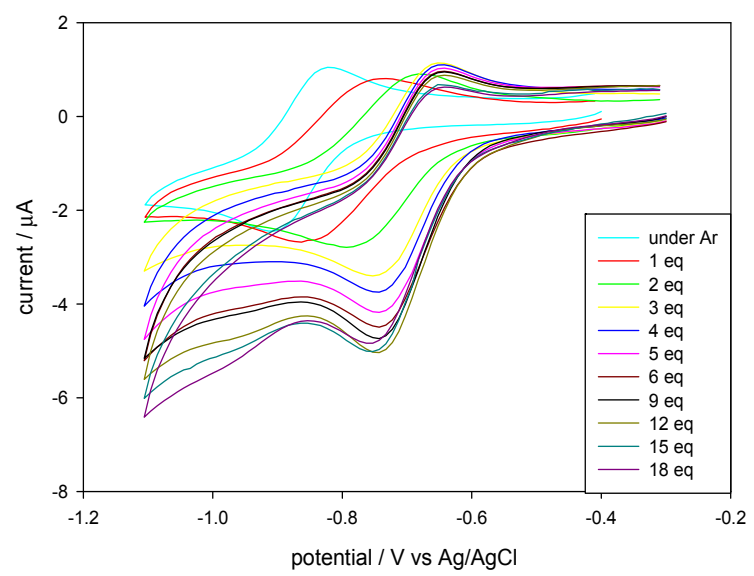

Figure 4 . The cyclic voltammetry of $\left[\mathrm{Fe}_{4} \mathrm{~S}_{4}(\mathrm{SPh})_{4}\right]^{2}$ at low concentrations of pentafluorothiophenol 


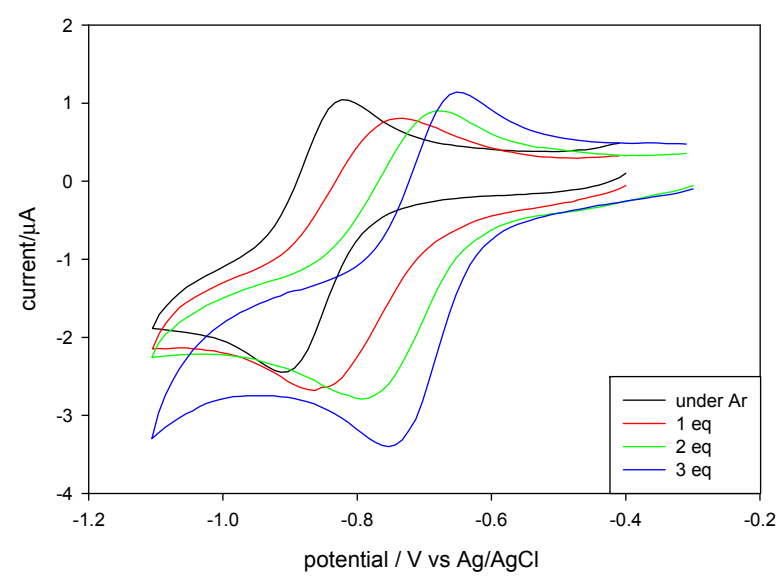

Figure 5. The cyclic voltammetry of $\left[\mathrm{Fe}_{4} \mathrm{~S}_{4}(\mathrm{SPh})_{4}\right]^{2}$ in the presence of high concentrations of pentafluorothiophenol

Figure 6 shows the variation of the peak current as a function of the concentration of pentafluorothiophenol. The current was enhanced with an increment of pentafluorothiophenol concentration, up to about 12 eq [12 mM]. After this concentration, the electrocatalysis became independent of the acid concentration.

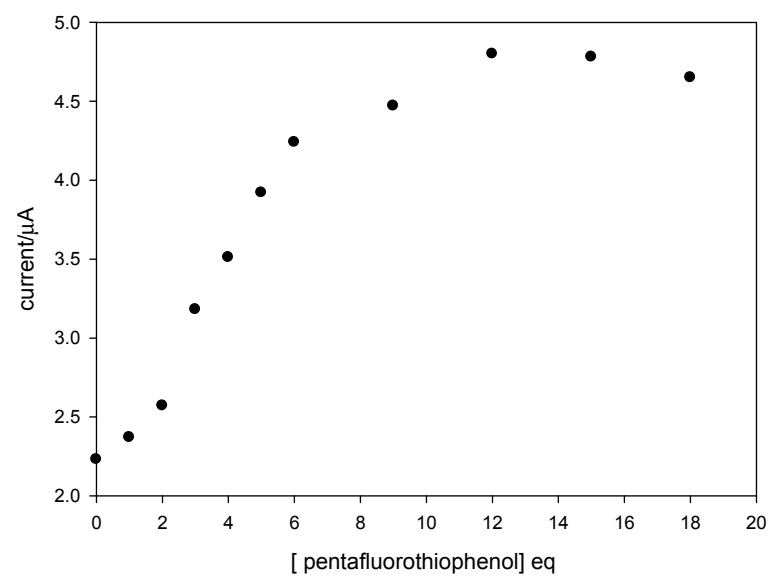

Figure 6. the peak current as a function of the concentration of pentafluorothiophenol

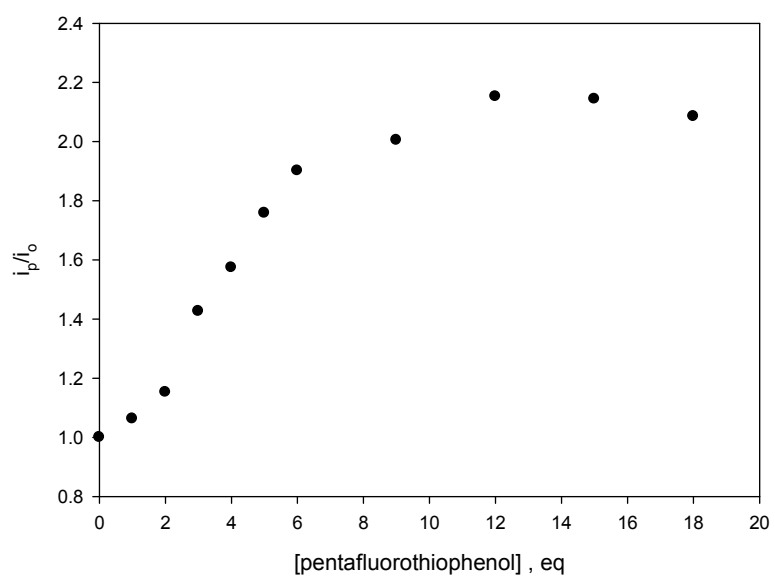

Figure 7. Effect of the acid concentration on $\mathrm{i}_{\text {cat }}$ i0 ratio at a vitreous carbon electrode

The kinetics of the electrocatalysis of proton reduction by $\left[\mathrm{Fe}_{4} \mathrm{~S}_{4}(\mathrm{SPh})_{4}\right]^{2}$ were also investigated. The peak catalytic current was normalized by dividing the peak current for the catalyzed process by that of the uncatalyzed process $\left(\mathrm{i}_{\text {cat }} / \mathrm{i}_{\mathrm{o}}\right)$ 
at $100 \mathrm{mVs}^{-1}$; this simplify the subsequent analysis by eliminating the surface area, along with the catalyst concentration and its diffusion coefficient (DuBois, 2013). Figure 7 shows a plot of the $i^{1}{ }_{\text {cat }} / i_{0}$, where $i^{1}$ cat is the peak current measured at $100 \mathrm{mVs}^{-1}$ for the primary catalysis in the presence of different concentrations and $\mathrm{i}_{0}$ is the peak current measured for the first one-electron reduction step at the same scan rate in the absence of the proton source. It is important to mention that at the vitreous carbon electrode, the values of $\mathrm{i}_{\mathrm{cat}} / \mathrm{i}_{0}$ become independent of the acid concentration at $c a 12 \mathrm{M}$ in DMF- containing $0.1 \mathrm{M}\left[\mathrm{NBu}_{4}\right]\left[\mathrm{BF}_{4}\right]$.

Following the approach of Dubois and others (DuBois, 2013), the rate constant $\mathrm{k}^{\mathrm{C}}{ }_{\text {obs }}$ at the carbon electrode can be estimated from the $\mathrm{i}_{\text {cat }} / \mathrm{i}_{0}$ data using the relationship shown in Equation 1.1, where $F, R$, and $T$ are the Faraday constant, the gas constant, and the temperature respectively, and $\mathrm{n}$ is the number of electrons involved in the turnover with $\mathrm{i}_{\text {obs }}$, measured at the potential where the current approaches a plateau at $-0.98 \mathrm{~V} \mathrm{vs} \mathrm{Ag} / \mathrm{AgCl}$. The value of $\mathrm{k}_{\text {obs }}$ is $18.9 \mathrm{~s}^{-1}$.

$$
\mathrm{K}_{\mathrm{obs}}=0.1992\left(F v / R^{2} n^{2}\right)\left(\mathrm{i}_{\mathrm{cat}} / \mathrm{i}_{0}\right)^{2}
$$

\subsection{Preparative Electrocatalysis}

Preparative bulk electrolysis reduction of protons in the presence of $0.5 \mathrm{mM}\left[\mathrm{Fe}_{4} \mathrm{~S}_{4}(\mathrm{SPh})_{4}\right]^{2-}(2.5 \mu$ moles $)$ was carried out in a closed system at $-0.85 \mathrm{~V} v s \mathrm{Ag} / \mathrm{AgCl}\left(0.2 \mathrm{mM}-\left[\mathrm{NBu}_{4}\right]\left[\mathrm{BF}_{4}\right]-\mathrm{CH}_{3} \mathrm{CN} ; 296 \mathrm{~K}\right)$ using $18 \mathrm{mM}$ (18 equivalents, $\mathrm{H}^{+}$ $22.5 \mu$ moles) of pentafluorothiophenol as a source of protons. The decay in current was monitored during the course of the experiment, while the working electrode compartment was stirred at a constant rate during electrocatalysis. Figure 8 shows the relationship between the current and time.

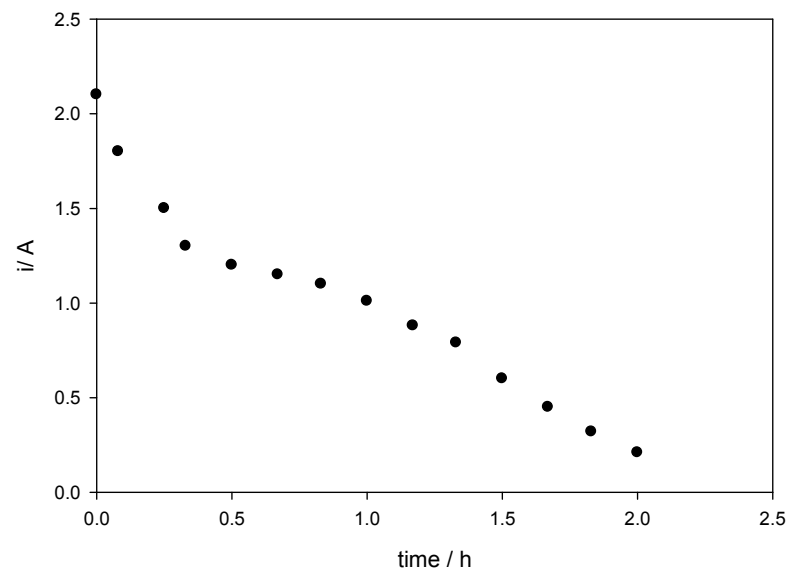

Figure 8. The relationship between the current and time $/ \mathrm{h}$

During proton reduction, the initial current rapidly decayed to a proportion of about $10 \%$ of the initial current before falling off toward the end of electrolysis; the gas phase of the cell was analyzed by gas chromatography. The gas chromatography (GC-TCD) test confirmed the formation of $\mathrm{H}_{2}$ with a current efficiency of ca $63 \%$ after two hours, which needed to be $3.2 \mathrm{C}$, while the yield of $\mathrm{H}_{2}$ was $10.4 \mu$ moles. $\mathrm{No}_{2}$ was formed at $-0.85 \mathrm{~V}$ vs $\mathrm{Ag} / \mathrm{AgCl}$ in the presence of $18 \mathrm{mM}$ of pentafluorothiophenol and absence of $\left[\mathrm{Fe}_{4} \mathrm{~S}_{4}(\mathrm{SPh})_{4}\right]^{2}$ (control experiment) (Table 1).

Table 1. Elecatrocatalysis results of proton reduction in the presence and absence of $\left[\mathrm{Fe}_{4} \mathrm{~S}_{4}(\mathrm{SPh})_{4}\right]^{2}$

\begin{tabular}{|c|c|c|c|c|c|c|c|}
\hline & $\begin{array}{l}\text { CPE } \\
\text { Potential } \\
(\mathrm{Ag} / \mathrm{AgCl})\end{array}$ & $\begin{array}{l}\text { Number of moles } \\
\text { of catalyst } \mu \text { mole }\end{array}$ & $\begin{array}{l}\text { Time of } \\
\text { experiment } / \mathrm{h}\end{array}$ & $\begin{array}{l}\text { Charge } \\
\text { coulomb/C }\end{array}$ & $\begin{array}{l}\text { Current } \\
\text { efficiency* } \\
\mathrm{H}_{2}\end{array}$ & $\begin{array}{l}\text { Chemical } \\
\text { yield \% }\end{array}$ & $\begin{array}{l}\text { T.N } \\
\mathrm{H}_{2}\end{array}$ \\
\hline $\begin{array}{l}\text { In the presence of } \\
{\left[\mathrm{Fe}_{4} \mathrm{~S}_{4}(\mathrm{SPh})_{4}\right]^{2-}}\end{array}$ & -0.85 & 2.5 & 2 & 3.2 & 63 & 46.3 & 4.1 \\
\hline Control experiment & -0.85 & 0 & 2 & 0.12 & 0 & 0 & 0 \\
\hline
\end{tabular}

In a separate experiment under the same conditions, the yield of $\mathrm{H}_{2}$ was studied by gas chromatography as a function of electrolysis time and the charge passed versus current efficiency. Clearly, the yield of $\mathrm{H}_{2}$ increased steadily in the first phase of the electrolysis and dropped off in the latter stages as the acid was consumed. The chemical yield of dihydrogen at the end of electrolysis, based upon the total acid available, was $43 \%$; the electrochemical results are shown in Table 2. At the end of the electrolysis, a charge of 3.6 coulombs was passed and $5 \mu$ moles of dihydrogen was detected in the headspace of the catholyte by thermal conductivity gas. All results show in figure 9 . 

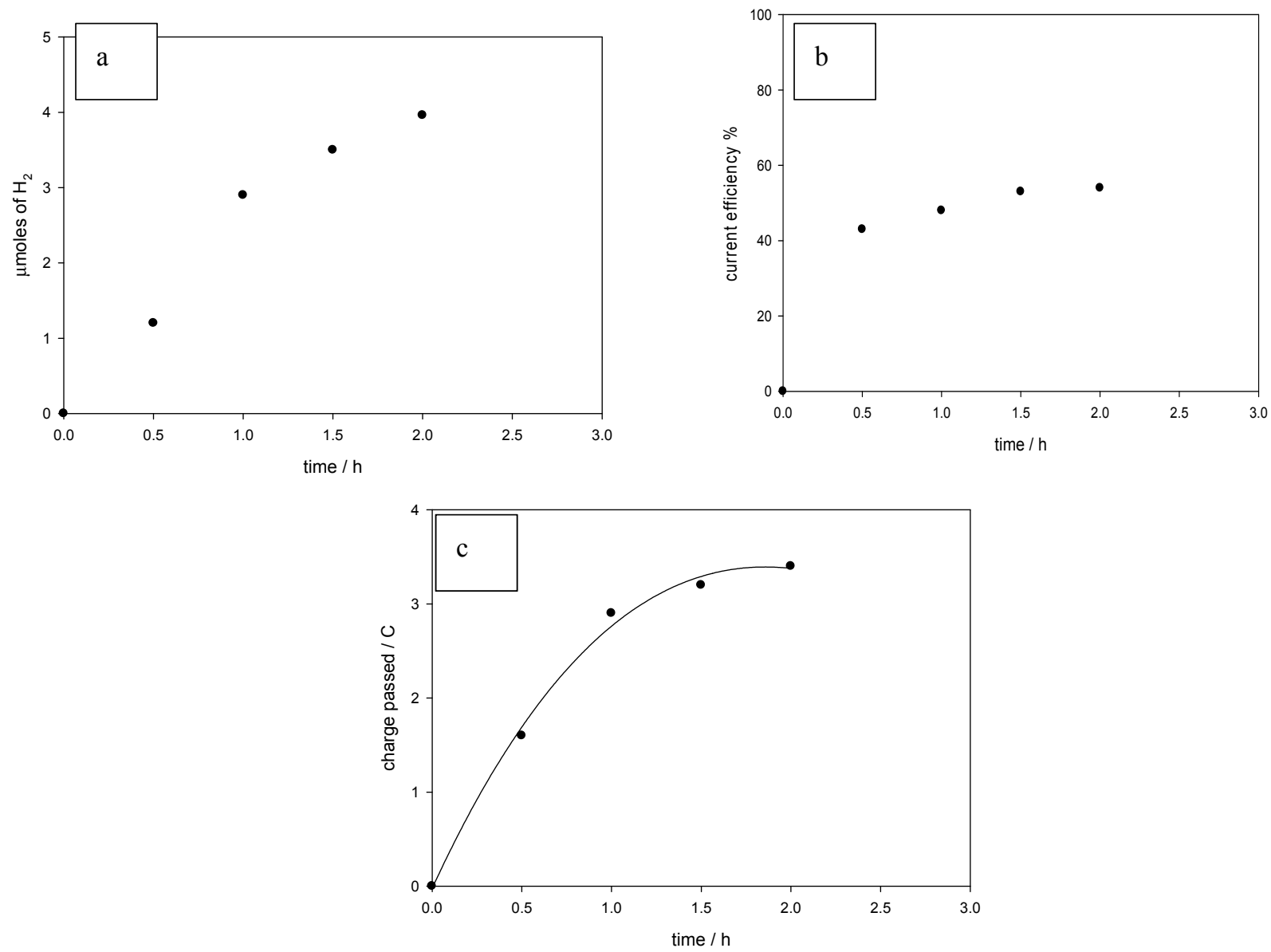

Figure 9. a) The yield of dihydrogen as a function of time / h, b) The current efficiency versus time / h. c). The charge passed versus time / $\mathrm{h}$

Table 2. Current efficiency and turnover numbers for electrocatalytic reduction of protons by $\left[\mathrm{Fe}_{4} \mathrm{~S}_{4}(\mathrm{SPh})_{4}\right]^{2-}$

\begin{tabular}{lcccc}
\hline Time/ $\mathrm{h}$ & 0.5 & 1 & 1.5 & 2 \\
Charge passed C & 1.6 & 2.9 & 3.2 & 3.4 \\
Current efficiency \% & 43 & 48 & 53 & 54 \\
Chemical yield \% & 13.3 & 32 & 40 & 43 \\
Number of $\mu$ moles of $\mathrm{H}_{2}$ & 1.2 & 2.9 & 3.5 & 3.96 \\
T.N & 1.2 & 2.9 & 3.5 & 3.96 \\
$\mu$ mole of electrons & 1.66 & 3.01 & 3.32 & 3.52 \\
\hline
\end{tabular}

3.4 Stability of Catalyst $\left[\mathrm{Fe}_{4} \mathrm{~S}_{4}(\mathrm{SPh})_{4}\right]^{2-}$

The figure 10 show that the stability of $\left[\mathrm{Fe}_{4} \mathrm{~S}_{4}(\mathrm{SPh})_{4}\right]^{2-}$ in DMF $-0.2 \mathrm{M}\left[\mathrm{Bu}_{4} \mathrm{~N}\right]\left[\mathrm{BF}_{4}\right]$ was studied in presence of $18 \mathrm{mM}$ of pentafluorothiophenol by comparing the difference in cyclic voltammetry before the addition of acid and after the electrocatalysis course (fig. 10). The peak current of the first reduction wave of $\left[\mathrm{Fe}_{4} \mathrm{~S}_{4}(\mathrm{SPh})_{4}\right]^{2-}$ before the addition of the acid source was $2.36 \mu \mathrm{A}$, while after the electrocatalysis course it was $1.742 \mu \mathrm{A}$. This confirms that $73 \%$ of $\left[\mathrm{Fe}_{4} \mathrm{~S}_{4}(\mathrm{SPh})_{4}\right]^{2-}$ was recovered after two hours. 


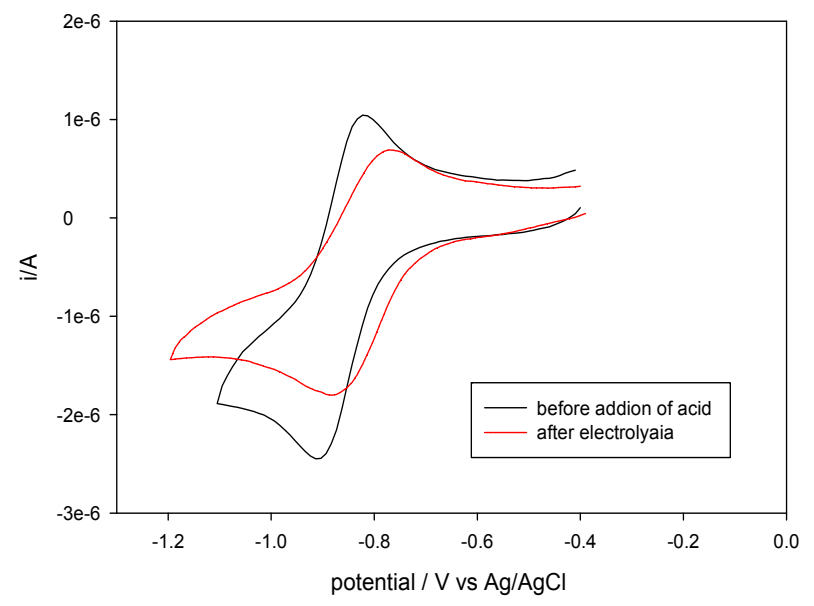

Figure 10. Cyclic voltammetry of $\left[\mathrm{Fe}_{4} \mathrm{~S}_{4}(\mathrm{SPh})_{4}\right]^{2-}$ before addition of pentafluorothiophenol and after electrolysis course

\section{Conclusion}

We have shown here that $\left[\mathrm{Fe}_{4} \mathrm{~S}_{4}(\mathrm{SPh})_{4}\right]^{2-}$ is a powerful catalyst for the reduction of proton into hydrogen at the carbon electrode in DMF- $\left[\mathrm{Bu}_{4} \mathrm{~N}\right]\left[\mathrm{BF}_{4}\right]$ at $23{ }^{0} \mathrm{C}$. The cyclic voltammogram of $\left[\mathrm{Fe}_{4} \mathrm{~S}_{4}(\mathrm{SPh})_{4}\right]^{2-}$ displayed two successive reversible reduction peaks; at $-0.98 \mathrm{~V}$ and $-1.72 \mathrm{~V} v s \mathrm{Ag} / \mathrm{AgCl}$. The HER occurs at $\mathrm{E}_{\mathrm{p}}=-0.98 \mathrm{~V}$ which is a significant shift comparing to $\mathrm{E}_{\mathrm{p}}=-1.3 \mathrm{~V}$; the reduction potential of pentafluorothiophenol without catalyst. The addition of high concentration of pentafluorothiophenol led to a positive shifting in the potential; while adding 18 equivalents, the potential shifts about $450 \mathrm{mV}$. The current efficiency to produce dihydrogen was about $63 \%$, while the chemical yield was $46 \%$ and the turnover number was 4 after $c a .2$ hours.

\section{Acknowledgments}

The author would like to thank Research Deanship, University of Hail, Kingdom of Saudi Arabia, for providing research fund (SC14012).

\section{References}

Alenezi, K. (2017). Electrocatalytic hydrogen evolution reaction using meso-tetrakis-(pentafluorophenyl) porphyrin iron(III) chloride. Int. J. Electrochem. Sci., 12, 812-818. https://doi.org/10.20964/2017.01.58

Artero, V., \& Savéant, J. M. (2014). Toward the rational benchmarking of homogeneous $\mathrm{H}_{2}$-evolving catalysts. Energy Environ. Sci., 7, 3808-3814. https://doi.org/10.1039/C4EE01709A

Aulice, M., \& Viswanthan, B. (2004). Electrochemical reduction of carbon dioxide. Rev. Proc Indian Natn Sci Acad., 3, 407-462.

Bak, T., Nowotny, J., Rekas, M., \& Sorrell, C. C. (2002). Photo-electrochemical hydrogen generation from water using solar energy. Materials-related aspects. Int. J. Hydrogen Energ., 27, 991-1022. https://doi.org/10.1016/S0360-3199(02)00022-8

Bhugun, I., Lexa, D., \& Savéant, J. M. (1996). Homogeneous catalysis of electrochemical hydrogen evolution by iron(0) porphyrins. J. Am. Chem. Soc., 118, 3982-3983. https://doi.org/10.1021/ja954326x

Christopher, D., \& Perutz, R. (2012). Advances in molecular photocatalytic and electrocatalytic $\mathrm{CO}_{2}$ reduction. Coord. Chem. Rev., 256, 2562-2570. https://doi.org/10.1016/j.ccr.2012.03.010

David (2015). Metal-Polypyridyl catalysts for electro- and photochemical reduction of water to hydrogen. A.C.S., 48, 2027-2036.

Evans, D., \& Pickett, C. (2003). Chemistry and the hydrogenases .Chem. Soc. Rev., 32, $268-275$. https://doi.org/10.1039/b201317g

Gary A. M. (1983). An introduction to cyclic voltammetry. J. Chem. Educ., 60, 697-701. https://doi.org/10.1021/ed060p697

Goh, G., Segal, B., Huang, J., Long, R., \& Holm, R. (1996). Synthesis and reactions of cubane-type Iron-Sulfur-Phosphine clusters, including soluble clusters of nuclearities 8 and 16. J. Am. Chem. Soc., 118, 11844-11853. https://doi.org/10.1021/ja9620200 
Han, Z. (2014). Fuel from water: the photochemical generation of hydrogen from water. Acc. Chem. Res., 47, 2537-2544. https://doi.org/10.1021/ar5001605

Kellett, R. M., \& Spiro, T. G. (1985). Cobalt porphyrin electrode films as hydrogen catalysts. Inorg. Chem., 24, 23782382. https://doi.org/10.1021/ic00209a012

Kelly, N. A., \& Gibson, T. L. (2008). Solar energy concentrating reactors for hydrogen production by photoelectrochemical water splitting. Int. J. Hydrogen Energ., 33, 6420-6431. https://doi.org/10.1016/j.ijhydene.2008.08.015

Koper, M. T. M. (2013). Theory of the transition from sequential to concerted electrochemical proton-electron transfer. Phys. Chem. Chem. Phys., 15, 1399-1407. https://doi.org/10.1039/C2CP42369C

Kumar, B., Smieja, J. M., \& Kubiak, C. P. (2010). Photoreduction of $\mathrm{CO}_{2}$ on p-type silicon using Re(bipy-But)(CO) ${ }_{3} \mathrm{Cl}$ : photovoltages exceeding $600 \mathrm{mV}$ for the selective reduction of $\mathrm{CO}_{2}$ to CO. Phys. Chem. C, 114, 14220-14229. https://doi.org/10.1021/jp105171b

Maria, J. (2007). Electrochemical carbon dioxide reduction- fundamental and applied topics. Journal of the University of Chemical Technology and Metalluragy, 42, 333-344.

Que, L., Bobrik, R., \& Ibers, H. H. (1974). Synthetic analogs of the active sites of iron-sulfur proteins. VII. Ligand substitution reactions of the tetranuclear clusters $\left(\mathrm{Fe}_{4} \mathrm{~S}_{4}(\mathrm{SR})_{42}\right.$-and the structure of $\left(\left(\mathrm{CH}_{3}\right)_{4} \mathrm{~N}_{2}\left(\mathrm{Fe}_{4} \mathrm{~S}_{4}\left(\mathrm{SC}_{6} \mathrm{H}_{54}\right)\right) . J\right.$. Am. Chem. Soc., 96, 4168-4178. https://doi.org/10.1021/ja00820a018

Tianbiao, L., Daniel, L., Du, B., \& Morris, R. (2013). Bullock-An iron complex with pendent amines as a molecular electrocatalyst for oxidation of hydrogen. Science, 18, 11798-11803.

\section{Copyrights}

Copyright for this article is retained by the author(s), with first publication rights granted to the journal.

This is an open-access article distributed under the terms and conditions of the Creative Commons Attribution license (http://creativecommons.org/licenses/by/4.0/). 